\title{
Research Paper Pesticide purchasing behaviour of farmers in Dharwad district
}

Correspondence to :

Mohasin A. Hosurkar Department of Agribusiness Management College of Agriculture, University of Agricultural Sciences,

Dharwad (Karnataka)

India

Email : mohasinshan620

@gmail.com

Paper History :

Received : 26.08.2017;

Revised : 18.01 .2018

Accepted : 02.02.2018
ABSTRACT : The study on pesticide purchasing behaviour of farmers was undertaken in all the taluks of Dharwad district and from each taluk 24 farmers were selected randomly. Tabular analysis was used for analysing purchase pattern of pesticides, farmer preferences for purchasing of pesticides and promotional measures for the purchase of pesticides by the farmers. The results found that all 120 samples farmers quoted that their source of purchase was from agro service centre. With regard to mode of purchase for pesticides majority 70 per cent of the farmers used to purchase on cash basis. Regarding time of purchase, as many as 87.5 per cent of farmers were used to purchase one day before spraying. As for the season of purchase the result revealed that most of the farmers (94.16\%) made purchases pesticides during Kharif season. The analysis of farmer preferences for purchasing of pesticides revealed that majority of the farmers 86.66 per cent opined that brand image was the preference for purchasing of pesticides and Kisan Call Centre guidance (5\%) was the least factor as opined by the total respondents in the study area. The results of the promotional measures for the purchase of pesticides by the farmers shows that among 120 sample farmers, 110 farmers opined that field demonstration was the most influential promotional measures for the purchase of pesticides by the farmers which accounts for 91.66 per cent and fairs was the least promotional measures for the purchase of pesticides as opined by 12.50 per cent of the total surveyed respondents in Dharwad district.

KeY Words : Purchase pattern, Farmer preference, Kisan Call Centre, Promotional measures, Pesticides

How To Cite This PAPer : Hosurkar, Mohasin A. and Kerur, N.M. (2018). Pesticide purchasing behaviour of farmers in Dharwad district. Internat. Res. J. Agric. Eco. \& Stat., 9 (1) : 108-112, DOI : 10.15740/HAS/IRJAES/ 9.1/108-112. 